\title{
Study of the Nutritional Increase in Organic Composts Obtained by Aerobic Biostabilization in the Management of Food Wastes
}

\author{
Pedro Fagundes ${ }^{1}$, Fernanda Castro $^{2}$, Lucilaine Santos ${ }^{3}$, Samuel Castro ${ }^{1} \&$ Liséte Lange $^{4}$ \\ ${ }^{1}$ Federal University of Juiz de Fora - UFJF, Juiz de Fora, Minas Gerais, Brazil \\ ${ }^{2}$ University Centre of Formiga - UNIFOR-MG, Formiga, Minas Gerais, Brazil \\ ${ }^{3}$ Catholic Pontifical University of Minas Gerais - PUC-MG, Belo Horizonte, Minas Gerais, Brazil \\ ${ }^{4}$ Federal University of Minas Gerais - UFMG, Belo Horizonte, Minas Gerais, Brazil \\ Correspondence: Samuel Castro, Department of Sanitary and Environmental Engineering, Faculty of \\ Engineering, Federal University of Juiz de Fora, José Lourenço Kelmer St., University Campus, São Pedro, Juiz \\ de Fora, Minas Gerais, Brazil. E-mail: samuel.castro@ufjf.edu.br
}

Received: November 10, $2020 \quad$ Accepted: December 12, $2020 \quad$ Online Published: December 22, 2020

doi:10.5539/jms.v11n1p15

URL: https://doi.org/10.5539/jms.v11n1p15

\begin{abstract}
Composting is a sustainable alternative regarding an environmentally appropriate management of the organic fraction contained in the municipal solid wastes. To minimize nitrogen losses during the biostabilization process, due to ammonia volatilization, the present study aimed to evaluate the composting technique combined with the possible precipitation of struvite $\left(\mathrm{MgNH}_{4} \mathrm{PO}_{4} \cdot 6 \mathrm{H}_{2} \mathrm{O}\right)$. A mixture containing food wastes was subjected to different experimental composting conditions with synthetic chemicals of magnesium and phosphorus- -0.020 mol kg-1 (EXPI) and $1.8 \mathrm{~mol} \mathrm{~kg}^{-1}$ (EXPII), in addition to the control treatment (CONT). Experiments were carried out in closed systems, under forced aeration, over a period time of 56 days. In general, the addition of synthetic chemicals provided a nutritional increase in the organic composts obtained at the end of the experimental period in both conditions (EXPI and EXPII) compared to the treatment CONT. It was observed a total nitrogen conservation of about $21 \%$ and $122 \%$ in samples of composts obtained under the conditions EXPI and EXPII, respectively. Germination tests of lettuce seeds (Lactuca sativa) were also carried out to evaluate the agricultural applicability of the composts obtained in comparison with a commercial substrate (COM). A germination index with an average value of $87 \%$ was reached with the use of $100 \%$ of the compost obtained under the condition of greater conservation of total nitrogen (EXPII). Finally, the strategy considered for the conservation of nutrients in organic composts showed technical feasibility, indicating the formation of struvite and/or its analogues in the products obtained.
\end{abstract}

Keywords: aerobic biostabilization, composting; municipal solid waste, nitrogen conservation, struvite

\section{Introduction}

Globally, urbanization and population growth have been increasing the generation of solid wastes, leading to a series of environmental, social and economic challenges, especially in developing countries. Thus, to overcome these issues, effective strategies in solid waste management must be adopted taking into account the reduction, reuse, recycling, recovery, treatment and, then, final disposal (Guo et al., 2018; Onwosi et al., 2017).

Composting is an environmentally friendly technology for the proper destination of solid wastes, in which the organic fraction is converted into compost by a biological process that promotes the reduction of environmental pollution and nutrients cycling. According to Finatto et al. (2013), the use of that compost provides improvements in the physical, chemical, and biological properties of the soil, keeping it fertile and enabling high productivity in crops. Besides that, Pandey, Cao, Biswas and Vaddella (2016) reported that the adoption of natural fertilizers reduces the use of synthetic fertilizers.

Among the various options for the treatment of organic solid wastes, composting stands out due to its cost-benefit ratio, hygiene and the ability to convert waste into good quality fertilizers, a fact that meets the concepts of sustainable agriculture (Onwosi et al., 2017). In addition, composting as an alternative to landfill wastes favors the reduction of greenhouse gas emissions generated by the anaerobic degradation of the organic fraction (Cerda et al., 2018; Onwosi et al., 2017) and increases the lifetime of such final disposal equipment 
(Lino, 2007).

However, one of the weaknesses of the composting technique is the excessive nitrogen $(\mathrm{N})$ losses due to the ammonia $\left(\mathrm{NH}_{3}\right)$ volatilization, which contributes to the atmospheric pollution and promotes a depreciation of the final product, with a reduction in the nutritional quality of the compost (Cáceres, Malińska, \& Marfà, 2018; Kataki, West, Clarke, \& Baruah, 2016a; Wang \& Zeng, 2018).

In an incipient way, studies have been evaluating the conservation of nutrients during the composting process, with the supplementation of phosphorus $(\mathrm{P})$ and magnesium $(\mathrm{Mg})$ chemicals, aiming at the formation of struvite crystals - magnesium ammonium phosphate $\left(\mathrm{MgNH}_{4} \mathrm{PO}_{4} \cdot 6 \mathrm{H}_{2} \mathrm{O}\right)$, a product with low solubility and high fertilizer potential (Chan, Selvan, \& Wong, 2016; Jiang et al., 2016; Jeong \& Hawng, 2005; Wang, Selvam, Chan, \& Wong, 2013).

Commercial P-based fertilizers are obtained from phosphate rocks, a finite resource. Therefore, global reserves of such rocks are expected to deplete in the near future because of the growing demand for fertilizers. Thus, integrating sustainable processes that save natural resources in waste management contributes to the enhancement of the nutritional quality of organic composts, closing the $\mathrm{N}$ cycle (Kataki, West, Clarke, \& Baruah, 2016b). It is also important to highlight that struvite becomes interesting as a potential fertilizer, since it is a non-muddy crystal. In this sense, nutrients are released slowly, minimizing problems related to eutrophication of water bodies that may arise from the runoff of P-synthetic fertilizers (Kataki et al., 2016a).

The conservation of nutrients during the composting process is configured as a sustainable alternative in the environmentally appropriate management of solid wastes. For this reason, the present work aimed to evaluate the composting technique combined with the possible formation of struvite crystals as a strategy to increase the nutritional content of the organic compost obtained.

\section{Material and Methods}

In this study, a synthetic food waste prepared by mixing bread, rice, cabbage and boiled pork in the ratio of 13:10:10:5, respectively, was used in the experiments (Wong, Fung, \& Selvam, 2009; Wang et al., 2013; Chan et al., 2016). The use of synthetic food waste facilitates the comparison between different experiments and results reported in the literature, as well as the elimination of the heterogeneity of food wastes (Wang et al., 2013). A preliminary characterization of the waste mixture taken for composting, containing synthetic food waste and sawdust, the carbon (C) source used in the study, is shown in Table 1.

A previous comminution step was performed to obtain homogeneous particles of the food waste in composting (particle size $<1 \mathrm{~cm}^{3}$ ), favoring a good mixture in the reactional system (Chan et al., 2016; Wang et al., 2013). In addition, $\mathrm{C} / \mathrm{N}$ ratio of the waste mixture was set at 30 by the addition of sawdust (particle size $<5 \mathrm{~mm}$ ) (Cornell Waste Management Institute [CWMI], 1996).

Table 1. Physicochemical characterization — food waste, sawdust and mixture

\begin{tabular}{llll}
\hline Parameters & Food waste (1) & Sawdust (2) & Waste mixture $(1+2)$ \\
\hline Moisture (\%) & 51.5 & 9.7 & $34.6 \pm 0.92$ \\
Total organic carbon (\%) & 52.4 & 51.8 & $51.3 \pm 4.62$ \\
Kjeldahl nitrogen (\%) ${ }^{\mathrm{a}}$ & 3.3 & 0.59 & $1.6 \pm 0.14$ \\
C/N ratio & 16 & 88 & $32 \pm 5.7$ \\
\hline
\end{tabular}

Note. ${ }^{\text {a }}$ According to Wang et al., 2013.

The waste mixture composed of food and sawdust was destined to a $60 \mathrm{~L}$ bench composter system (Figure 1). At the bottom of that system, there was a drainage bed with expanded clay (small type-2215) and a PVC screen in order to avoid the contact between the waste mixture and the leachate generated in the process. In a position immediately above the drainage bed, side inlets were used to conduct forced aeration with a flow rate in the range of 0.6 to $1.6 \mathrm{~L} \mathrm{~min}^{-1} \mathrm{~kg}^{-1}$ of dry mass using compressors (Boyu SC-7500) (Chan et al., 2016; Wang et al., 2013). At the top of the composter system, an orifice promoted the purge of the gases generated in the process and the access for temperature monitoring.

Three different treatments were performed (Table 2). In the first one, Experiment I (EXPI), $\mathrm{Mg}(\mathrm{OH})_{2}$ and $\mathrm{NaH}_{2} \mathrm{PO}_{4}$ (Anidrol) were added as a supplementary source of $\mathrm{Mg}$ and $\mathrm{P}$, synthetic salts required for the struvite formation and, in the second treatment, called Experiment II (EXPII), supplementation of these synthetic salts was also carried out, differing only in terms of the amount added. The dosage of reagents at EXPI was performed based on the initial concentration of ammoniacal nitrogen $\left(\mathrm{N}^{\left.-\mathrm{NH}_{3}\right)}\right.$ quantified in the aqueous extract obtained 
from the waste mixture $\left(209.7 \mathrm{mg} \mathrm{kg}^{-1}\right)$. On the other hand, the supplementation of synthetic salts in EXPII occurred based on the concentration of total nitrogen available in the raw mixture $(1.6 \%)$. In this regard, in both experiments, the stoichiometric ratio equal to $1.0: 1.5: 1.5(\mathrm{~N}: \mathrm{P}: \mathrm{Mg})$ was set up based on the study developed by Castro, Araújo and Lange (2013), in the establishment of optimal precipitation conditions for struvite from aqueous systems with high ammonia content (Tansel, Lunn, \& Monje, 2018). The adjustment of the stoichiometric ratio and the establishment of the operational conditions took place on the first day of the experimental period through an aqueous solution that allowed the concomitant adjustment of the moisture to an optimal value of 55\%, as reported by Chan et al. (2016) and Wang et al. (2013). For the Control (CONT) treatment, used as reference, there was no addition of synthetic salts.

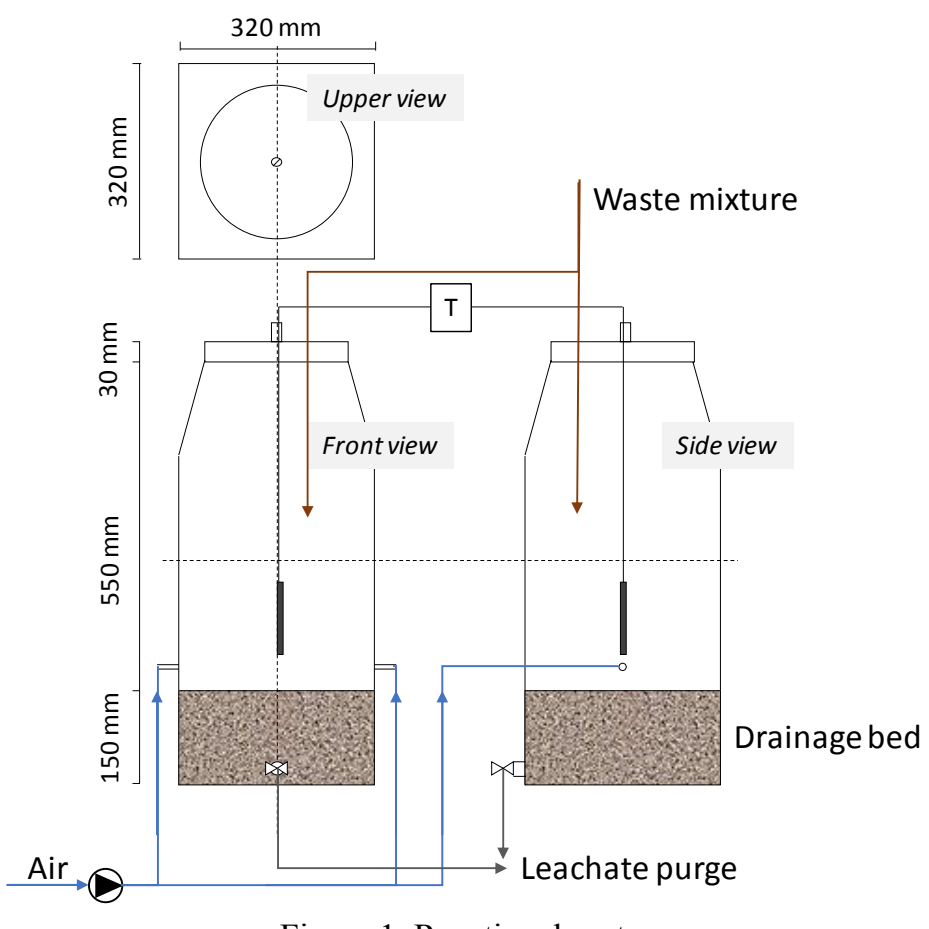

Figure 1. Reactional system

Table 2. Operational conditions and dosage of synthetic salts

\begin{tabular}{llll}
\hline Parameters & CONT & EXP I & EXP II \\
\hline Moisture $(\%)$ & 55 & 55 & 55 \\
$\mathrm{C} / \mathrm{N}$ ratio & 30 & 30 & 30 \\
$\mathrm{Mg}\left(\mathrm{mol} \cdot \mathrm{kg}^{-1}\right)$ & - & 0.020 & 1.8 \\
$\mathrm{P}\left(\mathrm{mol} \cdot \mathrm{kg}^{-1}\right)$ & - & 0.020 & 1.8 \\
\hline
\end{tabular}

\subsection{Sampling and Analytical Steps}

The waste mixture was spun once a week, over 56 days, aiming at homogenizing the residues, avoiding the formation of preferred aeration paths, and obtaining samples to perform physicochemical analyzes.

Weekly samples were collected, reduced to approximately $100 \mathrm{~g}$ of dry mass of the compost, as recommended by the Manual of Official Analytical Methods for Fertilizers and Correctives (Ministério da Agricultura, Pecuária

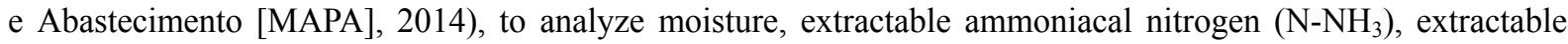
total Kjeldahl nitrogen (N-NTK), extractable organic nitrogen (N-Org), extractable total phosphorus (P-Tot), pH and electrical conductivity (EC); all in accordance with the Standard Methods for Examination of Water and Wastewater (American Public Health Association [APHA], 2012). In addition, in accordance with the Conselho Nacional do Meio Ambiente (CONAMA) Resolution No 481 (Brasil, 2017), the temperature of the composter system was measured daily (HT-9815 Digital K Thermocouple) throughout the entire experimental period.

The collected samples were taken to the incubator at $65^{\circ} \mathrm{C}$, until constant weight, as recommended by MAPA (2014), and, when necessary, the moisture was adjusted to 55\% through the addition of deionized water (CWMI, 
1996).

The analyzes, performed in triplicate, were carried out in aqueous extract, obtained from the composted residue, applying an adapted methodology (Associação Brasileira de Normas Técnicas [ABNT], 2004; Jeong \& Hwang, 2005; Jiang et al., 2016; MAPA, 2014; Yuan, 2018). The dry mass (DM) of the compost extract was mixed in deionized water, in the proportion $1: 10 \mathrm{~m} \mathrm{~m}-1$, and then subjected to stirring at $30 \pm 2 \mathrm{rpm}$ for 30 minutes (Agitator Wagner - LUCADEMA). After remaining at rest for 10 minutes, the supernatant was filtered through a $1.6 \mu \mathrm{m}$ membrane, and the extract obtained was sent for analysis. The $\mathrm{pH}$ was obtained using a $\mathrm{pH}$ meter mPA210 MS (Tecnopon) and the EC was obtained using a conductivity meter GEHAKA CG 1800 . In addition, at the end of the process, samples of the obtained compost were sent to Scanning Electron Microscopy (SEM Inspect/S50) coupled to Energy Dispersive X-ray (EDS - Edax/Genesis) for analysis.

The data obtained were subjected to analyzes of consistency and adherence to the normal distribution, preliminary assessments that supported the adoption of the Kruskal Wallis non-parametric statistical test, at 5\% significance level, in the comparative analysis between the results obtained in the different treatments. For this purpose, it was used the statistical package Statistica 8.0 (StatSoft, 2007).

\subsection{Germination Test of Seeds}

In order to evaluate the applicability of the composts produced as potential fertilizers, a seed germination index test was carried out (Silva et al., 2008). The test was conducted in a protected environment, located in the UNIFOR-MG Formiga-MG Brazil, in Cwa climate, classified according to the Köppen climate classification, and with averages of temperature and rainfall of $20.6{ }^{\circ} \mathrm{C}$ and $1437 \mathrm{~mm}$, respectively. Lettuce seeds (Lactuca sativa) were used, with $98 \%$ germination and $100 \%$ purity, according to the manufacturer, and 2 seeds per cell were sown in propylene trays (200 cells each), under a 50\% black shade screen (Figure 2). The layout used was completely randomized, with a $3 \times 3$ factorial, in which there were three substrates (CONT, EXPI e EXPII), obtained under the conditions evaluated in the present study, and three concentrations of mixture with commercial organic compost (COM) $(50 \%, 75 \%$ and $100 \%)$, composed of peat, pine powder and vegetable charcoal, enriched with macro and micronutrients. In total, 30 repetitions were performed under the conditions shown in Table 3, plus the COM.

Table 3. Factorial design—compost application tests

\begin{tabular}{lll}
\hline Experimental conditions & & \\
\hline $50 \%$ CONT $+50 \%$ COM & $75 \%$ CONT $+25 \%$ COM & $100 \%$ CONT $+0 \%$ COM \\
$50 \%$ EXPI $+50 \%$ COM & $75 \%$ EXPI $+25 \%$ COM & $100 \%$ EXPI $+0 \%$ COM \\
$50 \%$ EXPII $+50 \%$ COM & $75 \%$ EXPII $+25 \%$ COM & $100 \%$ EXPII $+0 \%$ COM \\
\hline
\end{tabular}

The final count of the germination percentage took place 25 days after sowing, using the formula $G=(N / A) * 100$, where $G$ is the germination percentage, $N$ is the number of germinated seeds and $A$ represents the total number of seeds sown. The software SISVAR 5.6 (Ferreira, 1998) was used in the analysis of data variance (ANOVA), at 5\% significance level. Finally, the Tukey's test, at $99 \%$ confidence, was used to identify significant deviations between means.

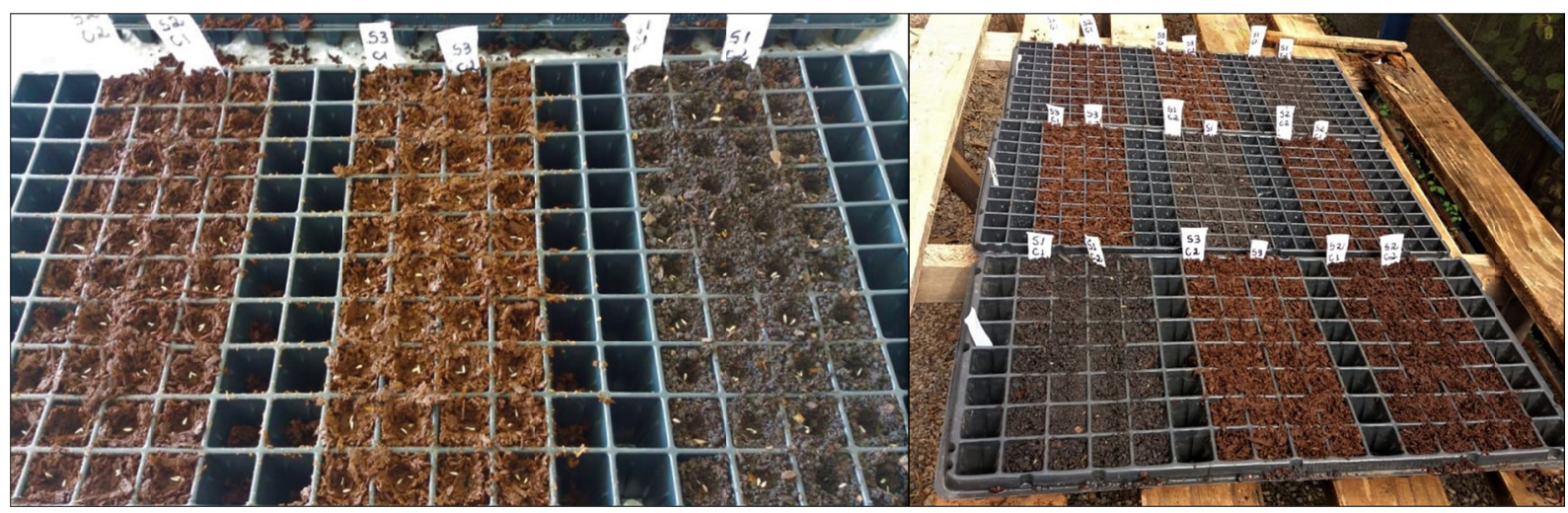

Figure 2. Germination test—sowing 


\section{Results and Discussion}

Figure 3 shows the evolution of temperature and moisture during the composting process, under the different conditions evaluated. The temperature recorded showed an evolution that is characteristic of an aerobic biodegradation process, with a significant increase in the first days, with well-defined thermophilic and mesophilic phases.

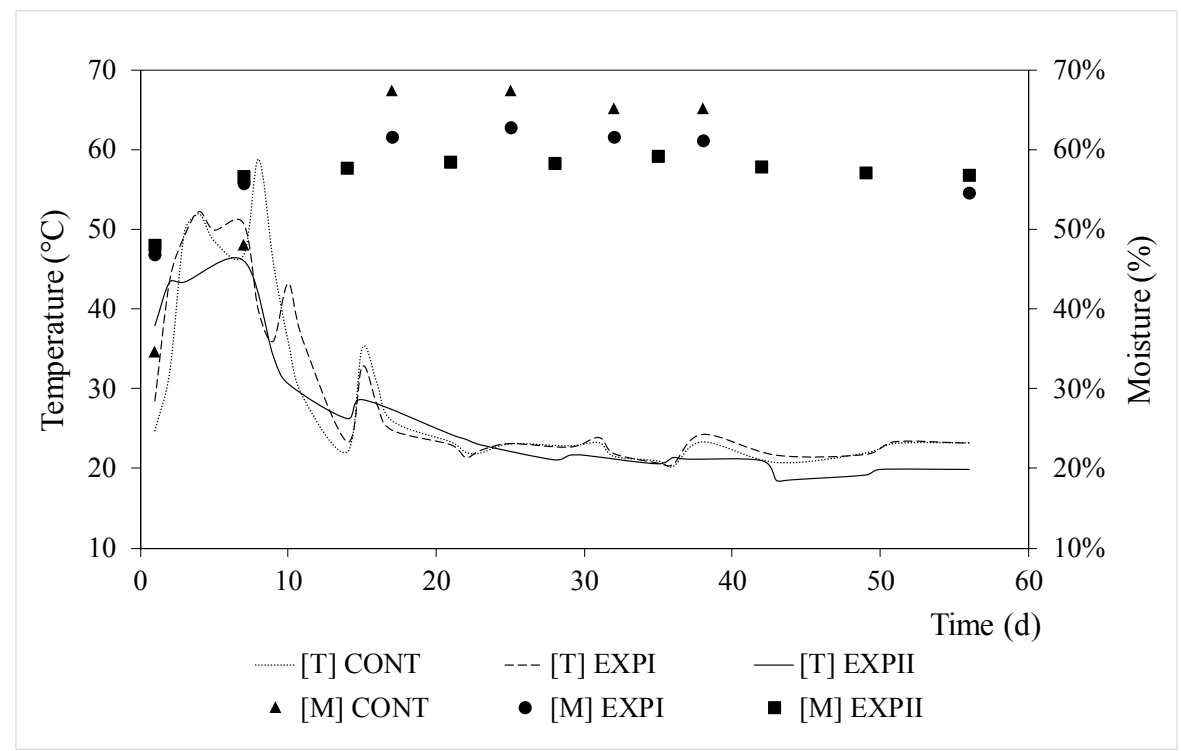

Figure 3. Evolution of temperature and moisture over time

The thermophilic phase of the treatments started on the third day, indicating that the organic matter of greater degradability and/or more bioavailable was decomposed quickly, providing nutrients necessary for microbial growth. However, the duration of this phase was different for each experiment, where for CONT it lasted until the tenth day, and, for the other conditions (EXPI and EXPII), until the eighth day. When analyzing the typical temperature range for the mesophilic phase $\left(25\right.$ to $\left.43^{\circ} \mathrm{C}\right)$, it was noticed that the end of this phase occurred after 21 days of experimentation for all conditions evaluated, where, from that moment, treatments started to register temperatures close to room temperature (Fernandes \& Silva, 1996; Cáceres et al., 2018; Onwosi et al., 2017). It is perceived the conformity with the results found in other studies, Wang et al. (2013) reported that the thermophilic phase in their study started from the second day, and Jeong and Hawng (2005) found that, regardless of the amount of $\mathrm{Mg}$ and $\mathrm{P}$ added, there was no difference regarding the beginning of the mesophilic phase, which started after the seventh day.

Synthetic salts supplementation performed in the treatments (EXPI and EXPII) may have resulted in a decrease in the duration of the thermophilic phase (approx. 4 days), when compared to the CONT (approx. 6 days). However, when analyzing EXPI and EXPII, it is noticed that the increase in the concentration of salts did not directly contribute to the reduction of this phase. The treatments showed good biological balance and process efficiency, evidenced by the temperature parameter, which, from the third day of the process, reached values in the range of $40-60^{\circ} \mathrm{C}$ under the different conditions (Fernandes \& Silva, 1996).

Regarding the cleaning of the compost, the treatments showed a thermophilic phase longer than three days, which, according to Zhang and Sun (2014), would be the condition for the compost not to present weed seeds and pathogens, in compliance with the sanitary requirements. However, even though some studies indicate that the cleaning of the compost is related to the exposure time and temperature recorded in the thermophilic phase (Ravindran \& Sekaran, 2010; Barthod, Rumpel, \& Dignac, 2018), it is emphasized that the steps of traceability of the raw material and the segregation at the source are essential for the quality of the process and product obtained.

The moisture recorded in the treatments varied over time, however, there was no significant difference between the conditions ( $\mathrm{p}$-value $>0.05$ ). In the first weeks, it was necessary to correct the moisture to $55 \%$, which was expected, due to the temperature increases registered in the process. However, due to the fact that composting 
takes place in a partially closed system, the system itself helped to maintain moisture, with no need for correction after the second week. Subtle elevations in moisture may be related to the predominance of anaerobic processes (Fernandes \& Silva, 1996), even so, for the different conditions, the moisture values remained within the ideal range (50-70\%) reported in the literature (Fernandez-Bayo, Yazdani, Simmons, \& VanderGheynst, 2018).

The addition of $\mathrm{Mg}$ and $\mathrm{P}$ salts may have influenced the behavior of $\mathrm{pH}$ and $\mathrm{EC}$ in the composting of food wastes, as shown in Figure 4. At the beginning of the process, the control treatment CONT registered a pH equal to 6.0; on the other hand, EXPI and EXPII reported $\mathrm{pH}$ values equal to 5.5 and 5.4, respectively, on the first day. Subsequently, there was an increase in the $\mathrm{pH}$ values, a typical characteristic of composting processes, which intensified in the last stages (Onwosi et al., 2017). The $\mathrm{pH}$ values of the conditions CONT and EXPI, after the thermophilic phase, remained in the range 7.0-8.0; an optimal range recommended for composting, according to Chan et al. (2016).

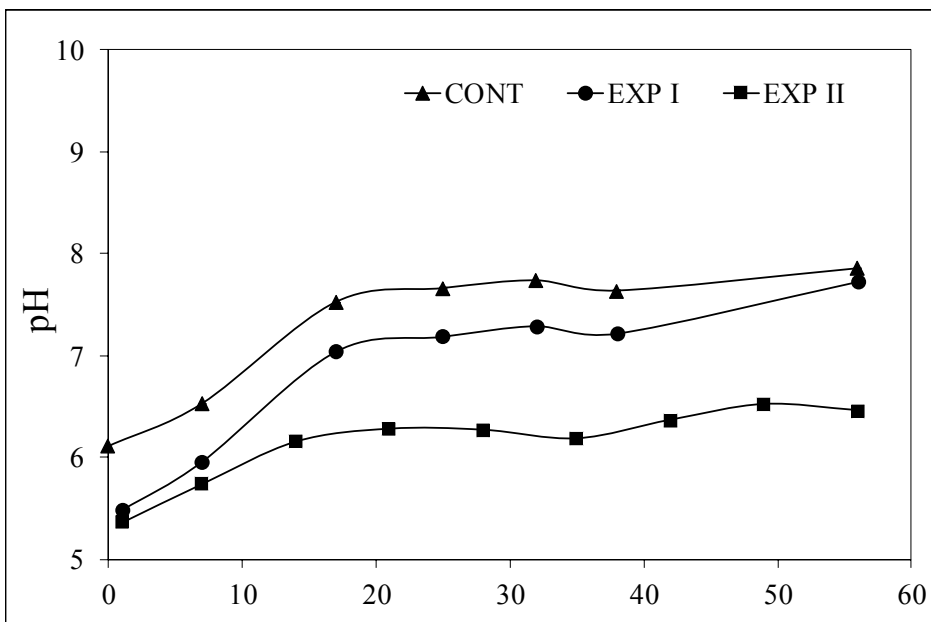

(a)

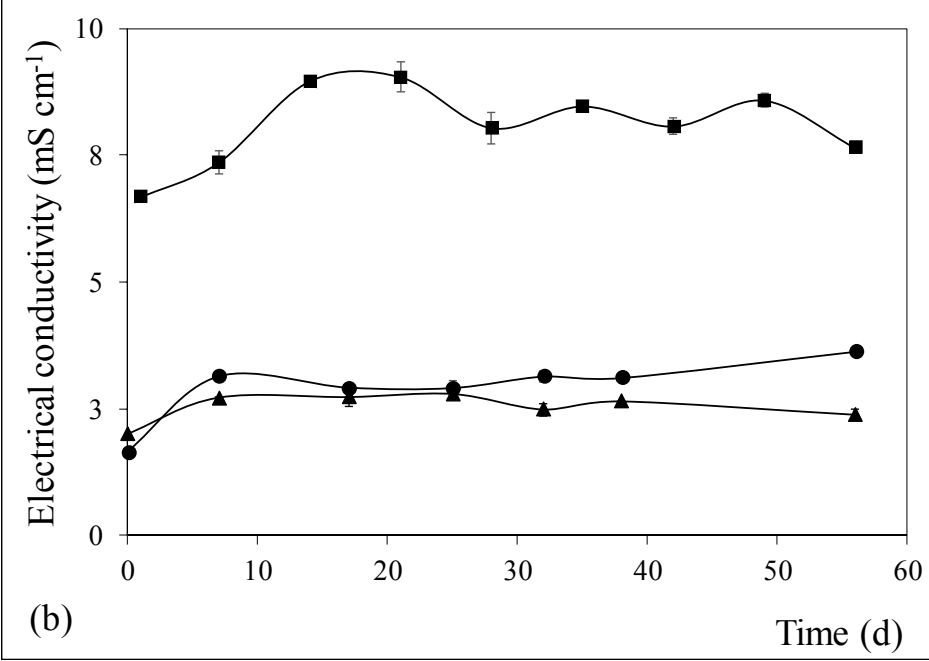

Figure 4. Monitoring of composting: (a) $\mathrm{pH}$ (b) electric conductivity

According to Wang et al. (2013), food waste has intense acidity. However, the excess of salts present in EXPII may have contributed to $\mathrm{pH}$ values about 1.3 times lower than those observed in the other treatments (CONT and EXPI), a significant difference at $95 \%$ confidence ( $p$-value $<0.05$ ), therefore not contributing to the buffering of organic acids produced during intensive degradation in the early stages of composting (Jeong \& Hwang, 2005; Wang \& Zeng, 2018).

In addition, $\mathrm{H}^{+}$ions are by-products of the struvite precipitation reaction, which, released in the reaction medium, promote a drop in the $\mathrm{pH}$ value and are directly related to the yield and efficiency of the reaction, as well as the 
consumption of Mg ions (Le Corre, Valsami-Jones, Hobbs, \& Parsons, 2009; Stratful, Scrimshaw, \& Lester, 2001).

The treatments EXPI and EXPII showed higher EC values (p-value $<0.05$ ) when compared to values obtained in the control treatment, an expected behavior due to the supplementation of inorganic salts. The EC of the treatments showed an increasing behavior during the initial stage, possibly due to the decomposition of complex organic compounds into soluble components (Wang et al., 2013; Chan et al., 2016).

Because composting is a biological process, phosphorus can be considered an important nutrient, however, its role during the evolution of composting is less known (Fernandes \& Silva, 1996). In general, values of total extractable P were higher in EXPI and EXPII, throughout the experimentation period, when compared to the control treatment (p-value $<0.05$ ), reaching a maximum value equal to $59.144 \pm 499 \mathrm{mg} \mathrm{P} \mathrm{k}^{-1}$ in dry mass of the compost obtained in the condition EXPII. Such a result is expected, due to the supplementation with $\mathrm{P}$ salts in the treatments.

Throughout the composting process, oscillations in the concentrations of total phosphorus were observed, in which the decrease registered in the treatments may be related to a greater interaction between phosphate ions and calcium and magnesium ions, in alkaline $\mathrm{pH}$, resulting in their temporary unavailability. As for the increase, this can be attributed to the soluble portion, previously immobilized by microbial cells, promoting an increase in organic phosphorus in the final product (Valente, Xavier, Pereira, \& Pilotto, 2016).

The concentration of extractable $\mathrm{N}-\mathrm{NH}_{3}$ observed in the treatments increased during the first week, where the

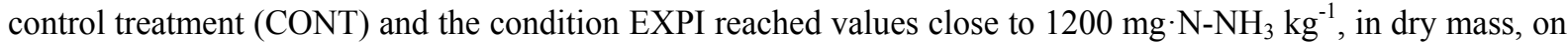
the seventh day of the process, as shown in Figure 5.

The increase in ammoniacal nitrogen available in the biomass is related to the transformation of N-Org into $\mathrm{N}-\mathrm{NH}_{3}$ (Sardá, 2016), coinciding with the active degradation of organic matter during the thermophilic phase (Chan et al., 2016; Wang et al., 2013). Therefore, even though there are different thermophilic phases for the conditions CONT and EXPI, there was no significant difference (p-value $>0.05$ ) between the ammoniacal nitrogen concentrations during the active phase of the process. In contrast, on the seventh day of experimentation, the condition EXPII showed $\mathrm{N}^{-\mathrm{NH}_{3}}$ values lower than those observed in the other treatments, close to $800 \mathrm{mg}$ $\mathrm{N}-\mathrm{NH}_{3} \mathrm{~kg}^{-1}$, possibly due to the lower temperatures recorded in such a condition for the thermophilic phase, resulting in the reduction of microbial activity.

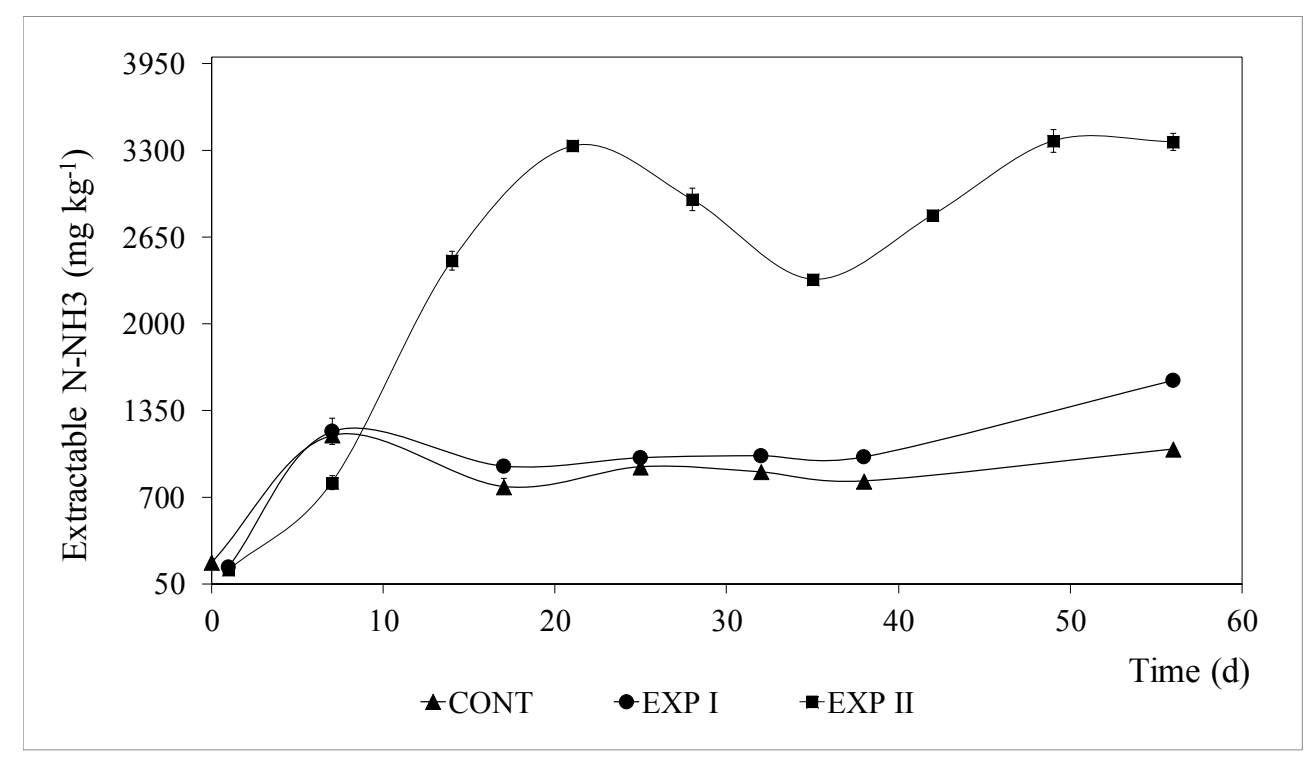

Figure 5. Evolution of extractable nitrogen throughout the process

At the end of the process, the analysis of the composts obtained in the treatments CONT, EXPI and EXPII indicated concentrations of $\mathrm{N}^{-N_{3}}$ equal to $1062 \pm 8 \mathrm{mg} \mathrm{kg}^{-1}, 1579 \pm 15 \mathrm{mg} \cdot \mathrm{kg}^{-1}$ and $3367 \pm 64 \mathrm{mg} \mathrm{kg}^{-1}$, respectively. Such results are in accordance with the study carried out by Wang et al. (2013), who reported an ammoniacal nitrogen concentration of up to $3518 \mathrm{mg} \mathrm{kg}^{-1}$ for composting conditions with supplementation of $\mathrm{P}$ 
and Mg salts. Studies point to the possibility of a second "peak" in the concentration of ammoniacal nitrogen during the composting process (Cáceres et al., 2018). Therefore, the increase in the concentration of $\mathrm{N}_{-} \mathrm{NH}_{3}$ after the 35th day of experimentation for the different conditions may be indicative of a late decomposition of the more complex organic fraction or of a difficult degradation.

Higher concentrations of $\mathrm{N}^{-\mathrm{NH}_{3}}$ in the treatments with the addition of salts may be related to the possible formation of struvite crystals. On the other hand, the temperature and $\mathrm{pH}$ values registered in the condition CONT during the initial stages, higher than those of the other conditions, may have contributed to a greater volatilization of $\mathrm{NH}_{3}$ and reduction of the nitrogen available in the compost.

According to the Kruskal-Wallis non-parametric test, only EXPII showed a significant difference (p-value $<0.05$ ) for results of $\mathrm{N}^{-\mathrm{NH}_{3}}$ in dry mass of compost, when compared to the other treatments. It was also evident that the analytical results reported for the conditions EXPI and CONT did not show significant differences between them, at $95 \%$ confidence.

The concentration of extractable N-NTK throughout the composting process increased in treatments EXPI and EXPII, reaching values equal to $1842 \pm 15 \mathrm{mg} \mathrm{kg}^{-1}$ and $3386 \pm 32 \mathrm{mg} \mathrm{kg}^{-1}$, respectively, at the end of the process This increase, according to Wang et al. (2013), is related to greater degradation of organic matter and lower

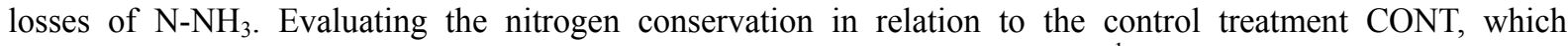
presented a compost with N-NTK concentration equal to $1525 \pm 116 \mathrm{mg} \mathrm{kg}^{-1}$ in dry mass, there was a total nitrogen conservation for the EXPI of approximately $21 \%$, which is in accordance with what has been reported in the literature (Chan et al., 2016; Wang et al., 2013). Finally, and also comparatively with the control treatment, EXPII presented a nitrogen conservation of approximately $122 \%$.

\subsection{SEM/EDS Analysis}

The analysis of samples of the compost obtained in the condition EXPII, with greater conservation of $\mathrm{N}-\mathrm{NH}_{3}$, did not present a well-defined orthorhombic crystalline structure, typical of struvite, but rather an amorphous structure, as shown in Figure 6. However, Sardá (2016) reported characteristics similar to crystals obtained in the study, amorphous solids with formation associated with the high number of dissolved ions present in food waste and with variable morphology due to physical and chemical processes and mechanisms. In this sense, the turning of the composting mass may have contributed to the formation of different structures, possibly due to the shear forces to which the crystals were subjected.

Wang et al. (2013) confirm this perception in their study, showing struvite crystals with irregular morphologies. According to the authors, this characteristic is the result of the formation of the crystals in a solid phase and difficult to separate from the compost.

According to Doyle and Parsons (2002), struvite formation occurs in two stages: nucleation and growth. Nucleation occurs when ions combine to form crystal embryos, and starts when there is supersaturation of the solution, where, under these conditions, the component ions combine to form small embryo crystals. The growth stage of the crystals occurs after nucleation, where the ions adhere to the surface of the solid particles formed. This process finishes with the end of the condition of supersaturation and the reestablishment of a new balance (Doyle \& Parsons, 2002). In this sense, it is inferred about the possible formation of phosphate crystals (approx. $1.6 \%$ ) on the surface of amorphous silicates (approx. 31\%), which possibly served as crystallization nuclei for composts such as struvite and its analogues (Tansel et al., 2018).

\subsection{Germination Test of Seeds}

A characterization of the organic composts obtained in the different conditions evaluated in this study, in addition to the commercial compost, taken to the germination test, is shown in Table 4. The EC of the commercial compost was considerably lower when compared to that of the other organic composts, especially in relation to EXPI and EXPII. Therefore, it is clear that, in fact, the addition of salts for the formation of struvite crystals results in an increase in EC. However, it is noteworthy that the compost obtained in the condition CONT also showed high EC when compared to the compost COM, so that part of the salts present in the treatments is the result of the composting process and of the waste used. With regard to $\mathrm{pH}$, it is observed that the composts obtained in the present study showed values close to neutrality, whereas the compost COM has greater acidity, with a $\mathrm{pH}$ value equal to 4.5 . 

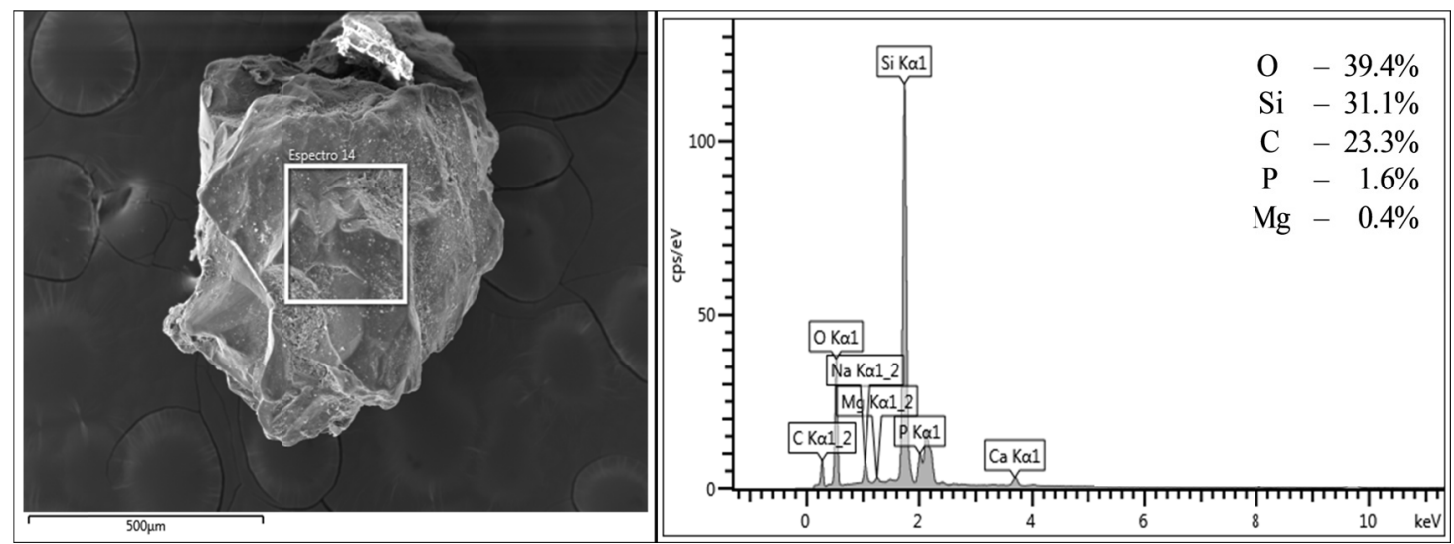

Figure 6. SEM/EDS analysis: Sample EXPII

Table 4. Chemical characterization: Comparison between organic compounds

\begin{tabular}{lllll}
\hline Parameter & COM & CONT & EXPI & EXPII \\
\hline $\mathrm{EC}\left(\mathrm{mS} \cdot \mathrm{cm}^{-1}\right)$ & 0.1 & 2.4 & 3.6 & 7.7 \\
$\mathrm{pH}$ & 4.5 & 7.9 & 7.7 & 6.5 \\
Extractable N-NH $\left(\mathrm{mg} \cdot \mathrm{kg}^{-1}\right)$ & 87 & 1062 & 1579 & 3367 \\
Extractable P-Tot $\left(\mathrm{mg} \cdot \mathrm{kg}^{-1}\right)$ & 2114 & 2315 & 2670 & 59144 \\
Moisture $(\%)$ & $18 \%$ & $57 \%$ & $55 \%$ & $57 \%$ \\
\hline
\end{tabular}

In the conditions evaluated in this study, it is noticed that the addition of salts resulted in an increase in the concentrations of ammoniacal nitrogen and total phosphorus. It is also noticed a certain relationship between the dosage of salts and the conservation of nitrogen, as observed for the compost EXPII, the condition with the highest supplementation of salts. The moisture content of the composts obtained under the conditions CONT, EXPI and EXPII showed values around 56\%, higher than those of the compost COM (18\%), possibly because they were submitted to an insufficient maturation time, a fact corroborated by the carbon content reported for the sample obtained in the condition EXPII (23.3\%), in analysis presented in Figure 6.

The average germination of the substrate COM, adopted as a control, was $93 \%$, a result higher than that of the treatments evaluated (CONT, EXPI and EXPII), with an average value equal to 80\%. Although the pH is close to neutrality, composts with high EC values can compromise the growth of plants due to the excessive release of soluble salts (Chan et al., 2016; Wang et al., 2013). Onwosi et al. (2017), indicate the value of $4 \mathrm{mS} \mathrm{cm}^{-1}$ as being ideal; however, Mota, Bôas, Ludwig, Fernandes and Folegatti (2011) point out that composts with superior EC can be used through proper management, considering the characteristics of the soil and the cultivation to be carried out.

The analysis of variance of the results obtained in the germination test showed at least one significant difference between the conditions evaluated ( $p$-value $<0.05$ ). When analyzing the germination averages by the Tukey's test, it is noticed that different concentrations determined different germinations, at $1 \%$ significance (Table 5). EXPII showed the best result when employed in a pure form (87\%), while the other treatments showed greater germination efficiency when applied in mixture. However, it is observed that the supplementation of $\mathrm{Mg}$ and $\mathrm{P}$ salts, with the consequent nutritional increase of the compost, resulted in good germinations, considering that the compost obtained in the condition EXPII presented an average germination result (approx. 82\%) higher than that obtained for the condition CONT (approx. 80\%).

Table 5. Germination tests for the organic composts obtained under the different experimental conditions

\begin{tabular}{llll}
\hline Concentration & CONT & EXPI & EXPII \\
\hline $50 \%$ & $87 \mathrm{Aa}$ & $87 \mathrm{Aa}$ & $73 \mathrm{Bb}$ \\
$75 \%$ & $87 \mathrm{Aa}$ & $70 \mathrm{Bc}$ & $87 \mathrm{Aa}$ \\
$100 \%$ & $67 \mathrm{Cb}$ & $73 \mathrm{Bb}$ & $87 \mathrm{Aa}$ \\
\hline
\end{tabular}

Note. Averages followed by the same uppercase letters in the lines and averages followed by the same lowercase letters in the columns do not differ from each other by the Tukey's test at $1 \%$ significance. 


\section{Conclusion}

With the present study, it is concluded that the addition of $\mathrm{Mg}$ and $\mathrm{P}$ salts during the composting process provided the nutritional increase of the products obtained, being a technically viable strategy in the management of solid food wastes. For the compost obtained in the experimental condition EXPII, with $1.8 \mathrm{~mol} \mathrm{~kg}-1 \mathrm{of}$ synthetic salts of $\mathrm{P}$ and $\mathrm{Mg}$ added to the composted mixture, conservation of $122 \%$ of total nitrogen was obtained compared to the condition CONT. In addition, the analysis of the samples of the composts gives an indication of the formation of struvite on the surface of amorphous solids, considered to be the nuclei of crystallization. Seed germination test was performed to evaluate the application of the composts obtained under the experimental conditions evaluated in the present study (EXPI and EXPII) compared to a commercial substrate (COM). Considerable germination percentages were found, with average values of $87 \%$ when the pure compost was applied, obtained in the condition of greater conservation of N-NTK (EXPII). Based on proper management, this result shows the feasibility of the application of the composts obtained in crops or as soil conditioners.

Finally, even though the conditions EXPI and EXPII have presented elements that show the conservation of nutrients in their composts, with potential results in their application, there is a need to explore other operational conditions, in addition to a more detailed investigation about the identification of struvite crystals and/or their analogs. It is also highlighted the need for a study focused on the evaluation of the economic viability of the composting process, considering the costs involved in the supplementation of synthetic salts.

\section{Acknowledgments}

The authors are grateful to the Brazilian National Council for Scientific and Technological Development (CNPq) and Foundation for Research Support of Minas Gerais (FAPEMIG) for their support.

\section{References}

ABNT. (2004). NBR 10.004: Resíduos Sólidos - Classificação. Rio de Janeiro.

APHA/AWWA/WEF. American Public Health Association (APHA), American Water Works Association (AWWA), Water Environment Federation (WEF). (2012). Standard methods for the examination of water and wastewater (22nd ed.). Washington, DC.

Barthod, J., Rumpel, C., \& Dignac, M. F. (2018). Composting with additives to improve organic amendments: A review. Agronomy for Sustainable Development, 38(2). https://doi.org/10.1007/s13593-018-0491-9

Brasil. (2017). Resolução $n^{\circ} 481$. Define critérios para produção de composto de resíduos sólidos orgânicos. Conselho Nacional do Meio Ambiente, Ministério do Meio Ambiente.

Cáceres, R., Malińska, K., \& Marfà, O. (2018). Nitrification within composting: A review. Waste Management, 72, 119-137. https://doi.org/10.1016/j.wasman.2017.10.049

Castro, S. R., Cota Araújo, M. A., \& Lange, L. C. (2013). Experimental design for the evaluation of struvite sedimentation obtained from an ammonium concentrated wastewater. Water Science and Technology, 68(7), 1607-1613. https://doi.org/10.2166/wst.2013.409

Cerda, A., Artola, A., Font, X., Barrena, R., Gea, T., \& Sánchez, A. (2018). Composting of food wastes: Status and challenges. Bioresource Technology, 248, 57-67. https://doi.org/10.1016/j.biortech.2017.06.133

Chan, M. T., Selvam, A., \& Wong, J. W. C. (2016). Reducing nitrogen loss and salinity during "struvite" food waste composting by zeolite amendment. Bioresource Technology, 200, 838-844. https://doi.org/10.1016/j.biortech.2015.10.093

CWMI. (1996). The Science and Engineering of Composting. Cornell University, Ithaca, NY. Retrieved October 2018, from http://compost.css.cornell.edu/science.html

Doyle, J. D., \& Parsons, S. A. (2002). Struvite formation, control and recovery. Water Research, 36(16), 3925-3940. https://doi.org/10.1016/S0043-1354(02)00126-4

Fernandes, F., \& Silva, S. M. C. P. (1996). Manual prático para a compostagem de Biossólidos. Londrina: Prosab, Finep.

Fernandez-Bayo, J. D., Yazdani, R., Simmons, C. W., \& VanderGheynst, J. S. (2018). Comparison of thermophilic anaerobic and aerobic treatment processes for stabilization of green and food wastes and production of soil amendments. Waste Management, 77, 555-564. https://doi.org/10.1016/j.wasman.2018.05.006 
Ferreira, D. F. (1998). Sisvar - sistema de análise de variância para dados balanceados (Version 5.6) [Software]. Lavras, MG: UFLA.

Finatto, J., Altmayer, T., Martini, M. C., Rodrigues, M., Basso, V., \& Hoehne, L. (2013). An importância da utilização da adubação orgânica na agricultura. Revista Destaques Acadêmicos, 5(4), 85-93.

Guo, W., Zhou, Y., Zhu, N., Hu, H., Shen, W., Huang, X., ... Li, Z. (2018). On site composting of food waste: A pilot scale case study in China. Resources, Conservation and Recycling, 132(May), 130-138. https://doi.org/10.1016/j.resconrec.2018.01.033

Jeong, Y. K., \& Hwang, S. J. (2005). Optimum doses of Mg and P salts for precipitating ammonia into struvite crystals in aerobic composting. Bioresource Technology, 96(1), 1-6. https://doi.org/10.1016/j.biortech.2004.05.028

Jiang, T., Ma, X., Yang, J., Tang, Q., Yi, Z., Chen, M., \& Li, G. (2016). Effect of different struvite crystallization methods on gaseous emission and the comprehensive comparison during the composting. Bioresource Technology, 217, 219-226. https://doi.org/10.1016/j.biortech.2016.02.046

Kataki, S., West, H., Clarke, M., \& Baruah, D. C. (2016a). Phosphorus recovery as struvite: Recent concerns for use of seed, alternative Mg source, nitrogen conservation and fertilizer potential. Resources, Conservation and Recycling, 107, 142-156. https://doi.org/10.1016/j.resconrec.2015.12.009

Kataki, S., West, H., Clarke, M., \& Baruah, D. C. (2016b). Phosphorus recovery as struvite from farm, municipal and industrial waste: Feedstock suitability, methods and pre-treatments. Waste Management, 49, 437-454. https://doi.org/10.1016/j.wasman.2016.01.003

Le Corre, K., Valsami-Jones, E., Hobbs, P., \& Parsons, S, P. (2009). Phosphorous recovery from waste water by struvite crysatllisation: A review. Critical Reviews in Environmental Science and Technology, 39(6), 433-477. https://doi.org/10.1080/10643380701640573

Lino, I. C. (2007). Seleção De Áreas Para Implantação De Aterros Sanitários: Análise Comparativa De Métodos. Masters Dissertation. Universidade Estadual Paulista, Rio Claro, SP, Brazil.

MAPA. (2014). Manual de métodos analíticos oficiais para fertilizante e corretivos. Secretaria de Defesa Agropecuária, Brasília.

Mota, P. R. D., Villas Bôas, R. L., Ludwig, F., Fernandes, D. M., \& Folegatti, M. V. (2011). Avaliação do pH e da condutividade elétrica do substrato sob níveis de fertirrigação e métodos de extração da solução. Revista Brasileira de Horticultura Ornamental, 17(2), 121. https://doi.org/10.14295/rbho.v17i2.707

Onwosi, C. O., Igbokwe, V. C., Odimba, J. N., Eke, I. E., Nwankwoala, M. O., Iroh, I. N., \& Ezeogu, L. I. (2017). Composting technology in waste stabilization: On the methods, challenges and future prospects. Journal of Environmental Management, 190, 140-157. https://doi.org/10.1016/j.jenvman.2016.12.051

Pandey, P. K., Cao, W., Biswas, S., \& Vaddella, V. (2016). A new closed loop heating system for composting of green and food wastes. Journal of Cleaner Production, 133, 1252-1259. https://doi.org/10.1016/j.jclepro.2016.05.114

Ravindran, B., \& Sekaran, G. (2010). Bacterial composting of animal fleshing generated from tannery industries. Waste Management, 30(12), 2622-2630. https://doi.org/10.1016/j.wasman.2010.07.013

Sardá, L. G. (2016). Efeito do uso de aditivos químicos no processo de compostagem de dejetos suínos. Doctoral Thesis. Universidade Federal de Santa Catarina, Florianópolis, Brazil.

Silva, E. A., Mendonça, V., Tosta, M. D. S., Oliveira, A. C., Reis, L. L. dos, \& Bardiviesso, D. M. (2008). Germinação da semente e produção de mudas de cultivares de alface em diferentes substratos. Semina: Ciências Agrárias, 29(2), 245. https://doi.org/10.5433/1679-0359.2008v29n2p245

StaSoft. (2007). STATISTICA (Version 8.0) [Software]. Retrieved December, 2018, from http://www.statsoft.com

Stratful, I., Scrimshaw, M. D., \& Lester, J. N. (2001). Conditions influencing the precipitation of magnesium ammonium phosphate. Water Research, 35(17), 4191-4199. https://doi.org/10.1016/S0043-1354(01)00143-9

Tansel, B., Lunn, G., \& Monje, O. (2018). Struvite formation and decomposition characteristics for ammonia and phosphorus recovery: A review of magnesium-ammonia-phosphate interactions. Chemosphere, 194, 504-514. https://doi.org/10.1016/j.chemosphere.2017.12.004

Valente, B. S., Xavier, E. G., Pereira, H. S., \& Pilloto, M. V. T. (2016). Compostagem de resíduos da filetagem 
de pescado marinho e casca de arroz. Revista Brasileira Saúde e Produção Animal, 17(2), 237-248. https://doi.org/10.1590/S1519-99402016000200011

Wang, S., \& Zeng, Y. (2018). Ammonia emission mitigation in food waste composting: A review. Bioresource Technology, 248, 13-19. https://doi.org/10.1016/j.biortech.2017.07.050

Wang, X., Selvam, A., Chan, M., \& Wong, J. W. C. (2013). Nitrogen conservation and acidity control during food wastes composting through struvite formation. Bioresource Technology, 147, 17-22. https://doi.org/10.1016/j.biortech.2013.07.060

Wong, J. W. C., Fung, S. O., \& Selvam, A. (2009). Coal fly ash and lime addition enhances the rate and efficiency of decomposition of food waste during composting. Bioresource Technology, 100(13), 3324-3331. https://doi.org/10.1016/j.biortech.2009.01.063

Yuan, J., Li, Y., Chen, S., Li, D., Tang, H., Chadwick, D., ... Li, G. (2018). Effects of phosphogypsum, superphosphate, and dicyandiamide on gaseous emission and compost quality during sewage sludge composting. $\quad$ Bioresource Technology, 270(September), 368-376. https://doi.org/10.1016/j.biortech.2018.09.023

Zhang, L., \& Sun, X. (2014). Changes in physical, chemical, and microbiological properties during the two-stage co-composting of green waste with spent mushroom compost and biochar. Bioresource Technology, 171(1), 274-284. https://doi.org/10.1016/j.biortech.2014.08.079

\section{Copyrights}

Copyright for this article is retained by the author, with first publication rights granted to the journal.

This is an open-access article distributed under the terms and conditions of the Creative Commons Attribution license (http://creativecommons.org/licenses/by/4.0/). 